ACTA THERIOLOGICA

Vol. 28, 26: $397-416,1983$

\title{
Food Consumption by Microtus agrestis and the Unsuitability of Faecal Analysis for the Determination of Food Preference
}

\author{
John PHILLIPSON, M. SARRAZIN-COMANS ${ }^{1} \&$ C. STOMATOPOULOS ${ }^{2}$
}

\begin{abstract}
Phillipson, J., Sarrazin-Comans M. \& Stomatopoulos C., 1983: Food consumption by Microtus agrestis and the unsuitability of faecal analysis for the determination of food preference. Acta theriol., 28, 26: 397-416 [With 6 Tables, 4 Figs. \& Plate XIII]

In the laboratory adult Microtus agrestis (Linnaeus, 1761) consumed an average of $21.4 \mathrm{~g}$ wet wt. $\left(=6.3 \mathrm{~g}\right.$ dry wt.) of fresh grass indiv ${ }^{-1} \mathrm{~d}^{-1}$ with an annual mean digestibility of $52.8 \%$. When four common species of food grass were on offer consumption in Autumn and Winter was directly proportional to availability. A preference for the more "succulent" species was exhibited in Spring and Summer. Over the year digestibility coefficients ranged between 33.6 and $67.8 \%$, the highest values occurring in Spring and Summer. Faecal analysis suggested an order of food preference different to that determined by direct observation, the differences being attributable to the differential "desirability" and "digestibility" of the food grasses during the course of the year.

[Animal Ecology Research Group, Zoology Dept., Oxford Univ., South Parks Road, Oxford, OX1 3PS, U.K.; 1 Universität Bonn, Institut für Angewandte Zoologie, An der Immenburg 1, D-53000 Bonn 1; 2 Zoological Lab., University of Patras, Patras, Greece].
\end{abstract}

\section{INTRODUCTION}

There are four main approaches to the quantitative study of the food habits of animals, (1) direct observation of feeding or food remains, (2) analysis of gut contents, (3) faecal analysis, and (4) food preference experiments. None of them is ideally suited to every type of animal and circumstance. In the case of the primarily grass feeding Microtus agrestis (Linnaeus, 1761) direct observation of food consumption under natural conditions is extremely difficult. Adoption of the exclosure approach of Chitty, Pimentel \& Krebs (1968) does not -permit separation of actual consumption from the amount of food removed but not eaten (Petrusewicz \& Macfadyen, 1970). Gut-content analysis, favoured by Hansson $(1970,1971)$ and Evans (1973), has the disadvantage of a) killing the animal, and b) reflecting only the composition of the most recent meal (Ferns, 1976). Faecal analysis, used by Godfrey (1953) and Ferns (1976), raises problems of a) differential digestibility of different food items, and b) differential digestibility of the "same" food item at different seasons. Laboratory experiments on food preference are subject to the major criticism of non-natural conditions.

Irrespective of the approach employed, current evidence generally 
supports the thesis that $M$. agrestis exercises some degree of selection in its choice of food items (Godfrey, 1953; Myllymäki, 1959; Chitty et al., 1968; Hansson, 1970, 1971; Evans, 1973 and Ferns, 1976). What remains uncertain is whether the results obtained by different methods of diet determination truly reflect the rank order of food preference.

In this paper we combine the laboratory approach of food preference experiments with that of faecal analysis and explore two hypotheses, namely: (1) Consumption of different food items by $M$. agrestis is directly proportional to the availability of those foods. (2) Diet composition as determined by faecal analysis reflects the rank order of preference for the available food items.

\section{MATERIAL \& METHODS}

\section{Background Information}

The field voles and food used in this study came from a limestone grassland (Rough Common - Nat. grid ref. SP 457 081) which forms part of the Wytham Estate of Oxford University. It is the same grassland used by Godfrey (1953) and Chitty et al. (1968) in their studies of feeding by M. agrestis.

At the time of the investigation the relative abundance of the main grass species comprising the grassland mosaic was Brachypodium pinnatum (L.) Beauv $>$ Bromus erectus Hunds. $\approx$ Arrenatherum elatius (L.) J. \& C. Pressl $>$ Dactylis glomerata L. (see Gibson, 1976 \& 1976a). Eleven other grass species were recorded but nowhere did they exceed 10 per cent of the local cover. Only the four most common species were used in the laboratory investigation of food preference.

\section{Food Preference Experiments}

Figure 1 shows in some detail the apparatus used in these studies. The main features to be noted are:

1. The provision of a central nest box with an opening into each of the four feeding arenas.

2. The four food-hoppers, each of which presents an equal area of access from its associated arena to the contained food supply.

3. The gridded floors of the feeding arenas, which allow food remains and faeces to fall into a collecting tray without being permanently moistened with urine.

4. The interlocking nature of the apparatus, which facilitated collection of food remains and faeces as well as cleaning at the end of each trial.

A total of 62 food preference trials were made between. June, 1979 and June, 1980. On each experimental occasion the following pre-trial procedure was adopted:

1. At least $1.2 \mathrm{~kg}$ of each of the four test grasses (B. pinnatum, B. erectus, $A$. elatius and $D$. glomerata) was collected fresh from the field and transported to the laboratory in labelled polythene bags.

2. In the laboratory the live (green) material was separated from the dead (brown), only the former being retained for the food preference trials.

3 . The green material of each species was mixed separately. 
4. The mixed material from each species was divided into individual lots of ca. $200 \mathrm{~g}$ fresh weight. These weights were recorded.

5. One $200 \mathrm{~g}$ lot was stored in a perforated metal container and kept as a control for subsequent determination of wet weight - dry weight relationships. The remaining lots were offered as food in the preference trials.

6. Each trial apparatus was allocated, at random, one $200 \mathrm{~g}$ lot of each of the four test grasses. The "arena" to which each grass species was allotted was also randomly chosen.

7. Taking each grass species in turn, the grass was used first to fill the appropriate food-hopper, surplus material being stored in the associated "sparefood" compartment.

8. The nest box was supplied with distinctively coloured, yellow, hay.

At this stage of assembly the apparatus was ready to receive the experimental animal. (N.B. In an attempt to avoid "conditioning" to any of the test grasses experimental animals were kept immediately prior to the trial - at least 2 days on a diet of laboratory pellets).

9. The randomly chosen experimental animal was weighed to the nearest $0.1 \mathrm{~g}$ on a "Pesola" spring balance and its sex noted.

10. The test individual was placed in the central nest box and the foodhopper/nest-box roof fixed in position. Water bottles were added.

11. The whole set-up was covered by a damp cloth in an attempt to ensure that the food supply was kept in a pristine condition.

12. During the course of each trial ( 48 to $72 \mathrm{~h}$ ) the cloth cover was kept damp by sprinkling it with water. Depleted food resources in the hoppers were replenished regularly from the "spare food" compartments.

The post-trial procedure can be summarised as:

13. Removal and reweighing of the test animal before returning it to a holding cage.

14. Removal of the "yellow" hay from the nest box, at the same time ensuring that the green grass mixed with it was returned to the appropriate food compartment.

15. Removal of nest box.

16. Noting the maximum/minimum temperatures recorded during the trial period.

At this point the partly dismantled apparatus was left for 3 to 4 days to allow urine to evaporate and faeces to dry.

17. Sequential dismantling of the remaining apparatus ( $\mathrm{E}$ to $\mathrm{A}$ in Fig. 1) allowed collection of the surplus food, food remains by grass species, and their allocation to appropriately labelled perforated containers for drying at 70 to $80^{\circ} \mathrm{C}$ over $24 \mathrm{~h}$. The total faeces production was also collected and similarly dried.

18. The dry weights of the non-consumed portions of each of the preffered grass species were determined to the nearest $0.01 \mathrm{~g}$, as were the dry weights of the faeces produced.

19. The "control" materials were used to determine the wet weight-dry weight relationships of each of the four test grasses.

Given the above information it was possible to calculate (a) the per-cent water content of the test grasses, (b) consumption of both separate and combined food items per individual vole per unit time in terms of dry and wet weights, (c) total 


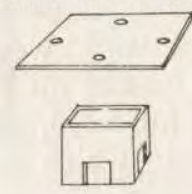

E

D
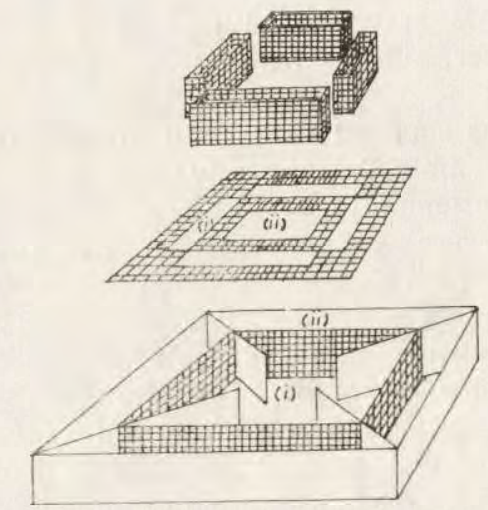

B
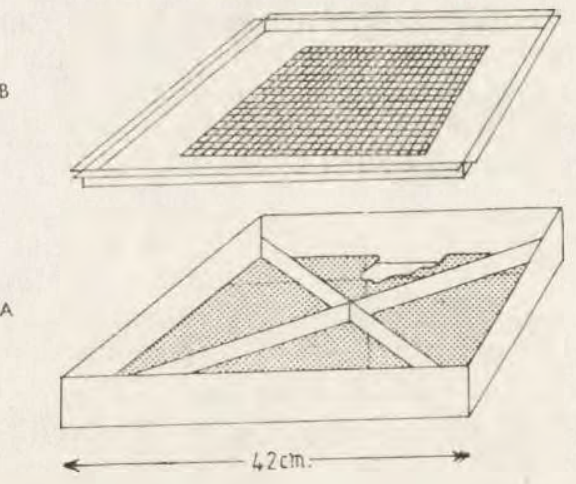

Fig. 1. An exploded view of the food preference apparatus.

A. The $42 \times 42 \times 6 \mathrm{~cm}$ collecting tray with a false bottom of muslin which retains faecal pellets and grass remains whilst allowing urine to drain away. The $3 \mathrm{~cm}$ high dividers separate the grass remains originating from the four feeding arenas. B. The $41 \times 41 \times 3 \mathrm{~cm}$ arena floor with a central $30 \times 30 \mathrm{~cm}$ area of metal grid through which faecal pellets and food remains fall. C. (i) The four feeding arenas separated by diagonal sheet metal walls which leave a central space for the nest box (ii) the "spare food" compartments. D. The $30 \times 30 \mathrm{~cm}$ metal mesh arena roof with apertures for (i) the four food hoppers and (ii) the central nest box. E. The $16 \times 4 \times 8 \mathrm{~cm}$ four metal food-hoppers. F. The $10 \times 10 \times 8 \mathrm{~cm}$ central nest box with a single opening on each of the four sides, thereby allowing free access to the feeding arenas. G. The $18 \times 18 \mathrm{~cm}$ nest box and food-hopper roof with apertures for water bottles. 
faeces production as dry weights, and (d) overall dry weight digestibility coefficients

/Total consumption - total faeces production $/ \times 100$

total consumption

Identification of Food Items in Faeces

Correct identification of the food items appearing in the faeces required the preparation of a reference collection of different grass parts. Permanent slides of the abaxial and adaxial cuticles of the leaf blades of $B$. pinnatum, $B$, erectus, $A$. elatius and $D$. glomerata were prepared according to a procedure based on, but modified from, Metcalfe (1960). In brief it consisted of:

1. The selection of a 1.5 to $2.0 \mathrm{~cm}$ piece from the middle section of a fresh leaf blade. Where the mid-vein was very prominent it was removed.

2. The softening of the chosen piece in water for 10 to 30 minutes.

3. Separation of the cuticle from the "softer" materials by scraping gently with a sharp, straight-edged scalpel. During this process the tissue was flooded from time to time with hypochlorite solution to ensure bleaching.

4. Washing the cuticle in water to remove all traces of hypochlorite solution.

5. Staining in Delafield's haematoxylin for 5 to 10 minutes, with subsequent washing and dehydration.

6. Preparation of the permanent slide with Euparal as mountant.

All preparations were photographed at a variety of different magnifications. The resulting prints were used in the identification of specific food items in the faeces produced during the food preference trials.

\section{Preparation of Slides of Faecal Material}

Slides of faecal material were prepared from individual pellets as follows:

1. Lightly grinding the dried faecal pellet in a miniature pestle and mortar.

2. Transferring the ground material, after the addition of distilled water and three drops of surfactant (= detergent), to a centrifuge tube and shaking well.

3. Removal of the supernatant fluid by centrifuging for approximately 7 minutes.

4. Two washes with distilled water, each followed by 7 minutes centrifugation.

5. Two washes with absolute alcohol, each followed by 7 minutes centrifugation.

6. Transference of the dehydrated material to a microscope slide, the effective cover slip area being $22 \times 50 \mathrm{~mm}$.

7. Preparation of a permanent mount with Euparal.

\section{Analysis of Faecal Preparations}

Using a combination of light-dark field microscopy each preparation was examined means of a $\times 16$ objective and a $\times 8$ ocular provided with a square grid consisting of 100 equal sized grid-cells. Each grid covered $0.36 \mathrm{~mm}^{2}$ of the slide and hence each grid-cell was equivalent to $0.0036 \mathrm{~mm}^{2}$. A systematic examination was made of 20 regularly spaced grids $\left(=7.20 \mathrm{~mm}^{2}\right)$ per slide. The spacing of the 
grids was arranged to encompass the $1100 \mathrm{~mm}^{2}$ of the cover slip, the locations being pre-determined by fixed co-ordinates on the mechanical stage of the microscope.

The observations made included the percentage frequency of occurrence, number and size of different categories of faecal fragments occurring within the grid fields. Where possible, fragments were categorized according to grass species, but in some instances it proved impossible to distinguish between $A$. elatius and D. glomerata because of the similarity in size and shape of some of their cells (see Plate XIII). A category $\mathrm{Ae} / \mathrm{Dg}$ was erected to receive information about such fragments. Other pieces could not even be allocated to a species group and were recorded as either unidentifiable (mainly fibres and parenchyma cells) or miscellaneous (mainly portions of cells, small hooks and hairs). The percentage frequency of occurrence and total number of categorized fragments per 60 grid fields was determined, also the size of each fragment estimated by visual comparison with a single grid-cell $\left(0.0036 \mathrm{~mm}^{2}\right)$ and assessing area to the nearest quarter grid-cell $\left(0.00045 \mathrm{~mm}^{2}\right)$.

\section{RESULTS}

\section{Food Preference Experiments}

Table 1 summarises the results of 62 trials made on 15 separate experimental occasions. Experiments 10 and 11 were conducted at a time of the year when green B. erectus was in short supply in the field, this species does not therefore figure in the results for February.

In common with other food preference trials on $M$. agrestis (Chitty et al., 1968; Hansson, 1971; Ferns, 1976) some animals in the present series showed a weight loss.

The mean wet weight of food consumed per day was $21.35 \pm 1 \mathrm{SD}$ $6.55 \mathrm{~g}_{\text {indiv }}^{-1}$, but statistically significant differences occurred between experiments made on different dates $\left(\chi^{2}=25.7\right.$, d.f. $\left.=14,0.02<p<0.05\right)$. These differences disappeared when dry weight consumption, with a mean value of $6.29 \pm 1 \mathrm{SD} 2.03 \mathrm{~g}$ indiv $^{-1} \mathrm{~d}^{-1}$, was considered $\left(\chi^{2}=8.57\right.$, d.f. $=14,0.80<p<0.90$ ).

Over the full series of trials the coefficient of digestibility (in terms of dry weight) equalled $52.8 \%$. Some variation occurred seasonally, digestibility coefficients being higher in Spring (March, April, May) and Summer (June, July, August) than in Autumn (September, October, November) and Winter (December, January, February); the respective coefficients were 53.7, 58.0, 44.3 and $50.6^{\circ} \%$.

Figure 2 shows the consumption of each of the four food types as a percentage of total consumption. The pattern of utilisation of each food clearly varied with season and the nature of this variation was explored by means of a factorial anovar for interaction (Table 2). In the case of both wet and dry weight consumption the interaction between food 


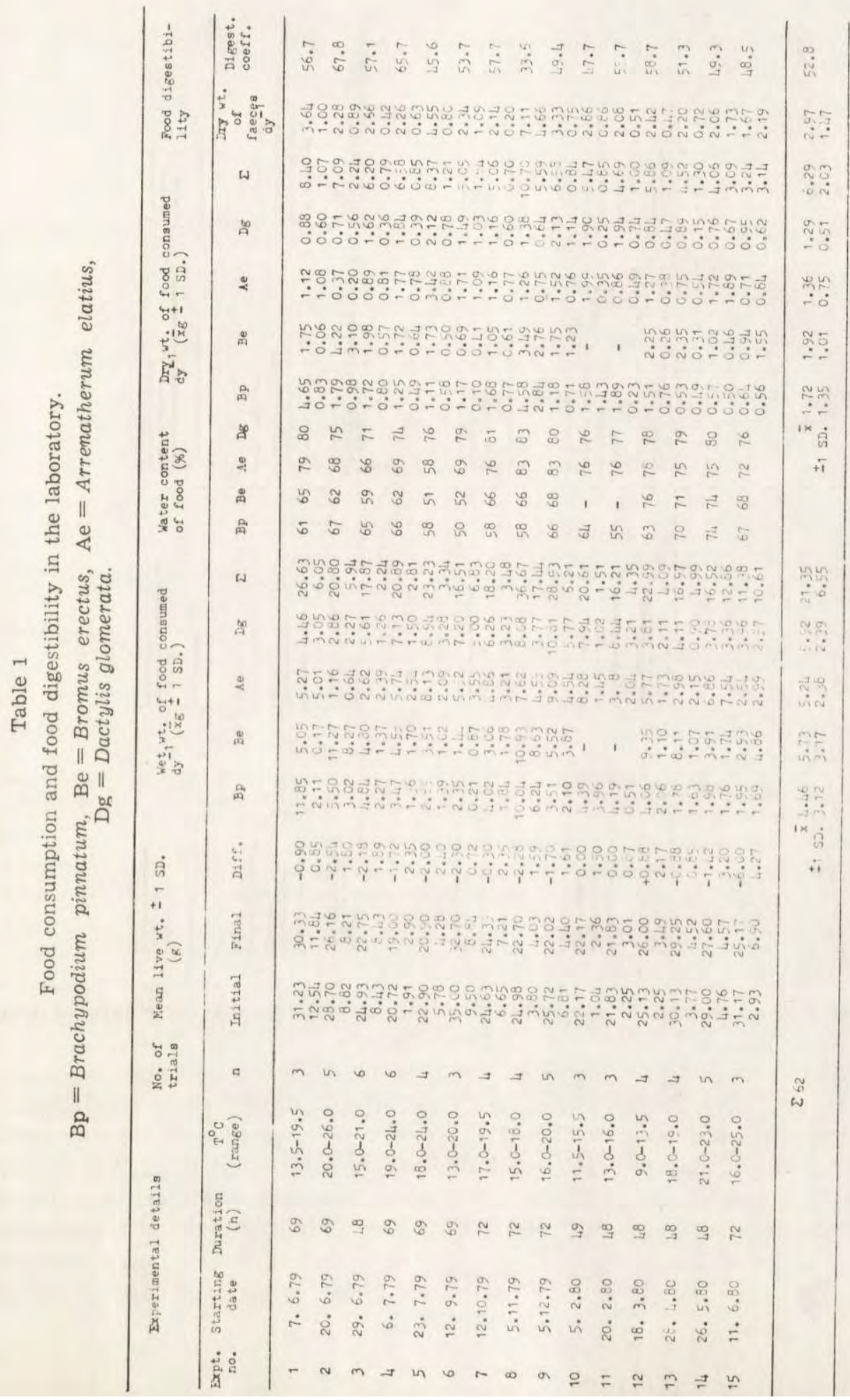



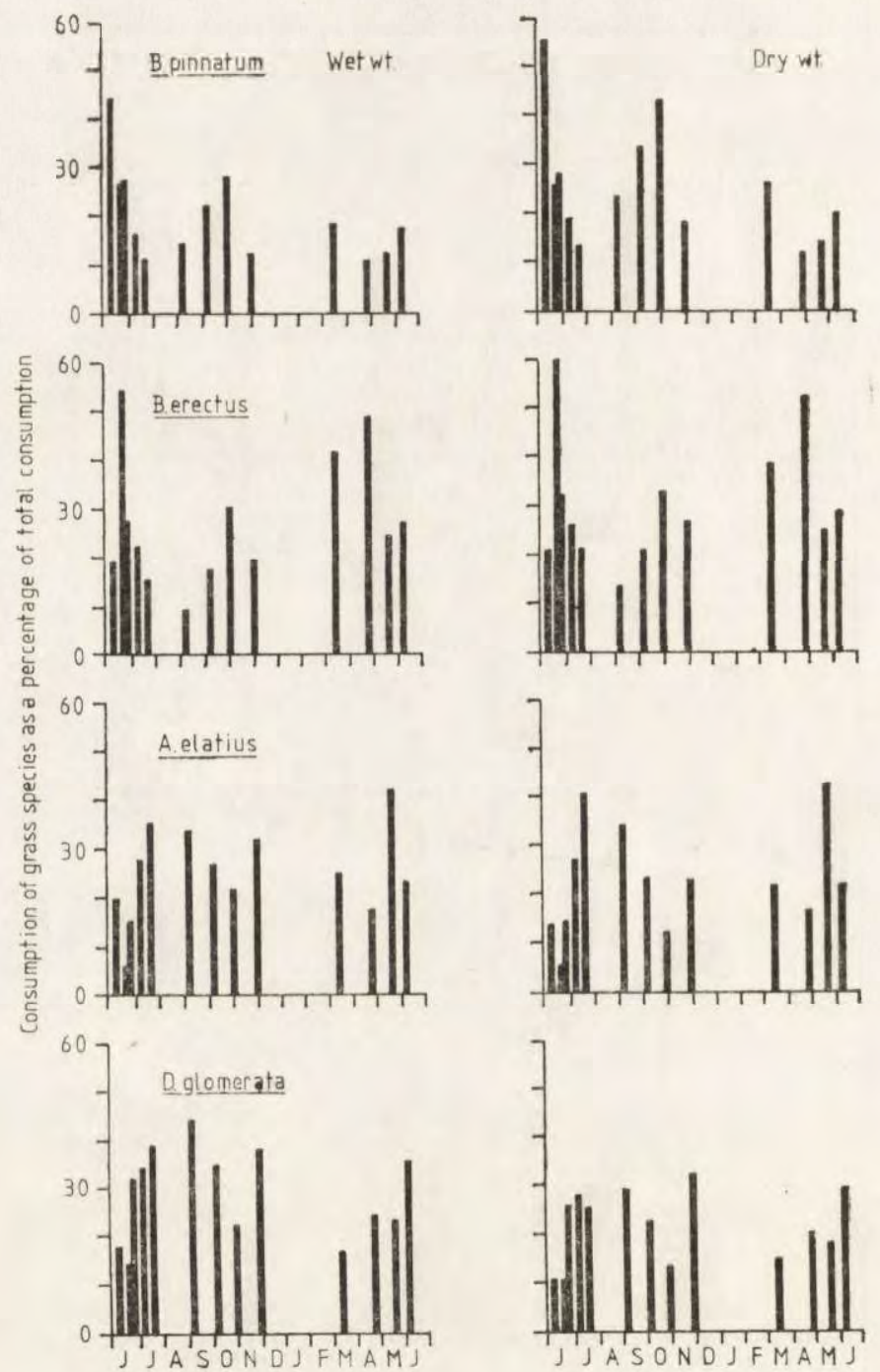

Fig. 2. Consumption of each of the four food grasses as a percentage of total consumption.

type and date proved to be highly significant. Under these conditions it was considered best to regard the series as consisting of several small experiments, one for each block or date. A separate analysis was carried out for each of the 13 blocks in which all four grass species were tested Table 3 summarises the results obtained with a) Friedman's non-parametric two-way analysis of variance $\left(\chi_{r}^{2}\right)$ and b) a parametric analysis of variance. The results of the two types of analysis are in broad 
Table 2

Results of factorial anovar to test for interaction between foods (treatment) and dates (blocks).

\begin{tabular}{|c|c|c|c|c|c|}
\hline $\begin{array}{l}\text { Sources of } \\
\text { variation }\end{array}$ & $\begin{array}{l}\text { Sums of } \\
\text { squares }\end{array}$ & $\begin{array}{l}\text { Degrees of } \\
\text { freedom }\end{array}$ & $\begin{array}{l}\text { Mean - } \\
\text { squarea }\end{array}$ & $\boldsymbol{F}$ & $\begin{array}{l}\text { Level of } \\
\text { ignificance }\end{array}$ \\
\hline & & \multicolumn{4}{|c|}{ Wet weleht consumption } \\
\hline Treatments & 50.64 & 3 & 16.88 & 1.49 & n. * $^{-}$ \\
\hline Blocks & 493.44 & 12 & 41.13 & 3.63 & 0.01 \\
\hline Interaction & 1033.45 & 36 & 28.71 & 2.54 & 0.01 \\
\hline Brror & 1947.63 & 172 & 11.32 & - & - \\
\hline \multirow[t]{2}{*}{ Total } & 3525.26 & 223 & - & - & - \\
\hline & & \multicolumn{4}{|c|}{ Dry veight consumption } \\
\hline Treatments & 15.50 & 3 & 5.17 & 5.02 & 0.01 \\
\hline Blocks & 47.37 & 12 & 3.95 & 3.83 & 0.01 \\
\hline Interaction & $127 \cdot 30$ & 36 & 3.54 & 3.44 & 0.01 \\
\hline Brror & 176.42 & 172 & 1.03 & - & - \\
\hline Total & 366.59 & 223 & - & - & - \\
\hline
\end{tabular}

Table 3

Food preferences as revealed by (a) Friedman's non-parametric two way analysis of variance $\left(\chi^{2}\right)$ and (b) a parametric analysis (Anovar).

\begin{tabular}{|c|c|c|c|c|c|c|c|c|}
\hline \multicolumn{3}{|c|}{ Iate } & \multicolumn{3}{|c|}{ Wet veight conaunption } & \multicolumn{3}{|c|}{ Dry velght consumption } \\
\hline & & & $x_{r}^{2}$ & Anover & $\begin{array}{c}\text { Pood } \\
\text { preference }\end{array}$ & $x_{x}^{2}$ & Anovaz & $\begin{array}{c}\text { Food } \\
\text { preferenco }\end{array}$ \\
\hline 7 & June & 1979 & n.a. & $\mathrm{n}, \mathrm{s}$. & - & $0.0 \%>0.05$ & $0.0 \mathrm{~K}<0.05$ & $B P>B C>A S>D E$ \\
\hline 20 & June & & 0.0150 .05 & $0.01<p 00.05$ & $B e>A p>D E A C$ & $0.001<000.01$ & $0.001<p<0.01$ & $B e>B P D D \in A \theta$ \\
\hline 29 & June & & r.s. & n, a, & - & n.s. & n.s. & $-\cdot$ \\
\hline 6 & July & & n.e. & $0.01 \% 0.05$ & $D E>A e>B e>D P$ & n. 0. & n.e. & - \\
\hline 23 & July & & $0.001<, 00.01$ & $0.05<5 \times 0.01$ & $D_{E}=A_{e}>B e>D P$ & n.s. & $0.001<p<0.01$ & $A e>D_{6}>B e>I_{P}$ \\
\hline & Augvat & & - & - & - & - & - & - \\
\hline 12 & September & & n.s. & n.e. & - & n.s. & n.s. & - \\
\hline 12 & Oetober & & n.s. & n. 8. & - & n.n. & n.e. & - \\
\hline & Novenber & & nies. & n, a. & - & n.8. & n,s. & - \\
\hline & Decenber & & n.s. & n.,a. & - & - & - & - \\
\hline & January & 1980 & - & - & - & - & - & - \\
\hline & Pebruary & & - & - & - & - & - & - \\
\hline $18:$ & March & & $0.001<\mathrm{p}<0.01$ & $0.001<p<0.01$ & Be $: A e>D e=B p$ & $0.01<p<0.05$ & $0.01<p<0.05$ & $B \cdot>A C=B I D D_{B}$ \\
\hline 28 & April & & $\infty 0.001$ & $0.001<0.01$ & $B e>D g>A e>B P$ & $0.01<p<0.05$ & $0.001<p<0.01$ & $B \cdot>A e=D e>B p$ \\
\hline 26 & May & & n.s. & n.z. & - & n. 8 . & n.s. & - \\
\hline 11 & Juna & & $n, s$. & n.s. & - & n.s. & n.e. & - \\
\hline
\end{tabular}


agreement and indicate that $M$. agrestis exhibited clear food preferences in June, July 1979 and March, April 1980, but not in other months. The order of preference for the four food types varied between seasons; $B$. erectus was the preferred food in March, April 1980 and possibly June 1979 , while $A$. elatius and $D$. glomerata were the most acceptable food in July, 1979.

On the basis of these results we conclude that a) M. agrestis exhibits a food choice in Spring and Summer, and b) consumption of different food items by $M$. agrestis is directly proportional to the availability of those foods only at certain times of the year, primarily Autumn and Winter.

\section{Identification of Food Items in Faeces}

The microphotographs shown in Plate XIII illustrate the range of cuticle-cell shapes, hooks and hairs associated with the four species of test grasses. These, and similar, photographs were used to aid the identification of grass fragments found in the faecal preparations. In the case of cuticle fragments it was relatively easy to distinguish those derived from B. pinnatum, B. erectus and A. elatius/D. glomerata.

\section{Analysis of Faecal Preparations}

To test the hypothesis that "diet composition as determined by faecal analysis reflects the rank order of food preference for the available food items" it was considered unnecessary to analyse all of the faecal pellets produced during the 62 trials. In practice we examined a random sample from the March and April 1980 trials and pellets from a contrasting trial where no food preference had been detected (May, 1980). For each of the three stated months pellets from four animals were analysed. Three slide preparations per animal were examined (i.e. $4 \times 3$ slides or $4 \times 60$ grid-fields per month, a total of $4 \times 21.6 \mathrm{~mm}^{2}$ ).

Table 4 shows the percentage frequency of occurrence of different food items in the faeces. Of the specifically identifiable foods it is clear that $B$. pinnatum occurred most frequently, followed by $B$. erectus and A. elatius/D. glomerata. As can be seen this sequence does not reflect the rank order of observed dry weight consumption.

Table 5 gives both the total number and total area of specific food categories occurring in the faecal slide preparations. As with the frequency of occurrence values the inference that $B$. pinnatum was the preferred food does not accord with the observed consumption values.

Because the mean fragment size of the different food categories varied 
Table 4

Percentage frequency of occurrence of different food items in the faeces. $\mathrm{Bp}=$ Brachypodium pinnatum, $\mathrm{Be}=$ Bromus erectus, $\mathrm{Ae}-\mathrm{Dg}=$ combined Arrenatherum elatius and Dactylis glomerata, Misc. = miscellaneous hooks and hairs, Unid. = unidentifiable fibres and cells.

\begin{tabular}{|c|c|c|c|c|c|c|c|c|}
\hline \multicolumn{3}{|c|}{ Experimental detallo } & \multicolumn{5}{|c|}{$\begin{array}{c}\text { Percentage frequency of occurrence in } \\
60 \text { grid-fields }\left(=21.6 \mathrm{~mm}^{2}\right)\end{array}$} & \multirow{2}{*}{$\begin{array}{l}\text { Rank order of } \\
\text { observed dry } \\
\text { weight consumption } \\
\text { (See Tables } 3 \& 6 \text { ) }\end{array}$} \\
\hline $\begin{array}{l}\text { Expt. } \\
\text { no. }\end{array}$ & $\begin{array}{c}\text { Trial } \\
\text { no. }\end{array}$ & $\begin{array}{l}\text { Animal } \\
\text { code }\end{array}$ & Bp & $\mathrm{Be}$ & $\begin{array}{l}\mathrm{Ae}- \\
\mathrm{Dg}\end{array}$ & Misc. & Enid. & \\
\hline 12 & 1 & 3D ? & 73.33 & 38.33 & 21.67 & 35.67 & 80.00 & $B p>A e / D e>B e$ \\
\hline 12 & 2 & $3 A C$ & $73 \cdot 33$ & 43.33 & 31.67 & 75.00 & 83.33 & $B e>B P>A e / D B$ \\
\hline 12 & 3 & 382 & 56.67 & 41,36 & 30.00 & 55.00 & 91.67 & $10 / D e B D B P$ \\
\hline \multirow[t]{2}{*}{12} & 4 & $36 \mathrm{e}$ & 90.00 & 25.00 & 6.67 & 63.33 & 96.67 & $B e>A e / D B B P$ \\
\hline & & $\vec{x}$ & 73.33 & 37.08 & 22.50 & & & $B e>A \theta / D \theta B p$ \\
\hline 13 & 1 & $40 \div$ & 61.67 & 30.00 & 15.00 & 45.00 & 80.00 & $\mathrm{Be}) \mathrm{Ae} / \mathrm{DB} \gg \mathrm{BP}$ \\
\hline 13 & 2 & LAC & 70.00 & .6 .67 & 20.00 & 28.33 & 96.67 & $\mathrm{Be}>\mathrm{Ae} / \mathrm{D} \otimes \mathrm{BP}$ \\
\hline 13 & 3 & $4 B$ o & 23.93 & 33.33 & 18.33 & 16.167 & 96.67 & $\mathrm{Be}>\mathrm{Ae} / \mathrm{DE}>\mathrm{BP}$ \\
\hline \multirow[t]{2}{*}{13} & 4 & 400 & $43 \cdot 33$ & 23.33 & 28.33 & 20.00 & 100.00 & $\mathrm{Be}>\mathrm{Ae} / \mathrm{DE}>\mathrm{BP}$ \\
\hline & & $\bar{x}$ & 52.08 & 33.33 & 20.42 & & & $\mathrm{Be}>\mathrm{Ae} / \mathrm{D} B \mathrm{BP}$ \\
\hline 14 & 1 & $50 \%$ & 58.33 & 31.67 & 28.33 & 21.67 & 96.67 & $A e / D B>B e>B P$ \\
\hline 14 & 2 & $5 \mathrm{~B}$ C & 31.67 & 140.00 & 18.33 & 36.67 & 88.33 & $\mathrm{Ae} / \mathrm{DE}_{\mathrm{E}}>\mathrm{Be}>\mathrm{Bp}$ \\
\hline 14 & 3 & $5 c c$ & 6.67 & 25.00 & 1.67 & 20.00 & 93.33 & $B p \geqslant B e>A e / D B$ \\
\hline \multirow[t]{2}{*}{14} & 4 & $5 E d$ & 33.23 & 21.67 & 35.00 & 17.67 & 93.33 & $A e / D E D E P B p$ \\
\hline & & $\bar{x}$ & 32.50 & $29 \cdot 8$ & 20.83 & & & $A e / D E>D e>9 p$ \\
\hline
\end{tabular}

(B. pinnatum: $0.004 \mathrm{~mm}^{2}$, range 0.001 to $0.034 \mathrm{~mm}^{2}$; B. erectus: $0.004 \mathrm{~mm}^{2}$, range 0.001 to $0.045 \mathrm{~mm}^{2} ; A$. elatius: $0.008 \mathrm{~mm}^{2}$, range 0.003 to 0.022 ; D. glomerata: $0.011 \mathrm{~mm}^{2}$, range 0.006 to $0.013 \mathrm{~mm}^{2} ; A$. elatius $/ D$. glomerata: $0.006 \mathrm{~mm}^{2}$, range 0.001 to $0.043 \mathrm{~mm}^{2}$; unidentifiable fibres and cells: $0.008 \mathrm{~mm}^{2}$, range 0.001 to $0.077 \mathrm{~mm}^{2}$; and miscellaneous hooks and hairs: $0.003 \mathrm{~mm}^{2}$, range 0.001 to $0.027 \mathrm{~mm}^{2}$ ) it is not surprising that only the miscellaneous category, with its fixed-shape items, showed a significant relationship between fragment number and area. A relationship which can be expressed by the least squares regression equation $y=0.14+0.002 x, \quad r^{2}=0.98, \quad p<0.001$, where $x$ represents number of fragments per 60 grid-fields and $y$, area of fragments in $\mathrm{mm}^{2}$.

A priori reasoning suggests that fragment area should be a better indicator of food consumption than fragment number, accordingly further attempts were made to try and establish concordance between 


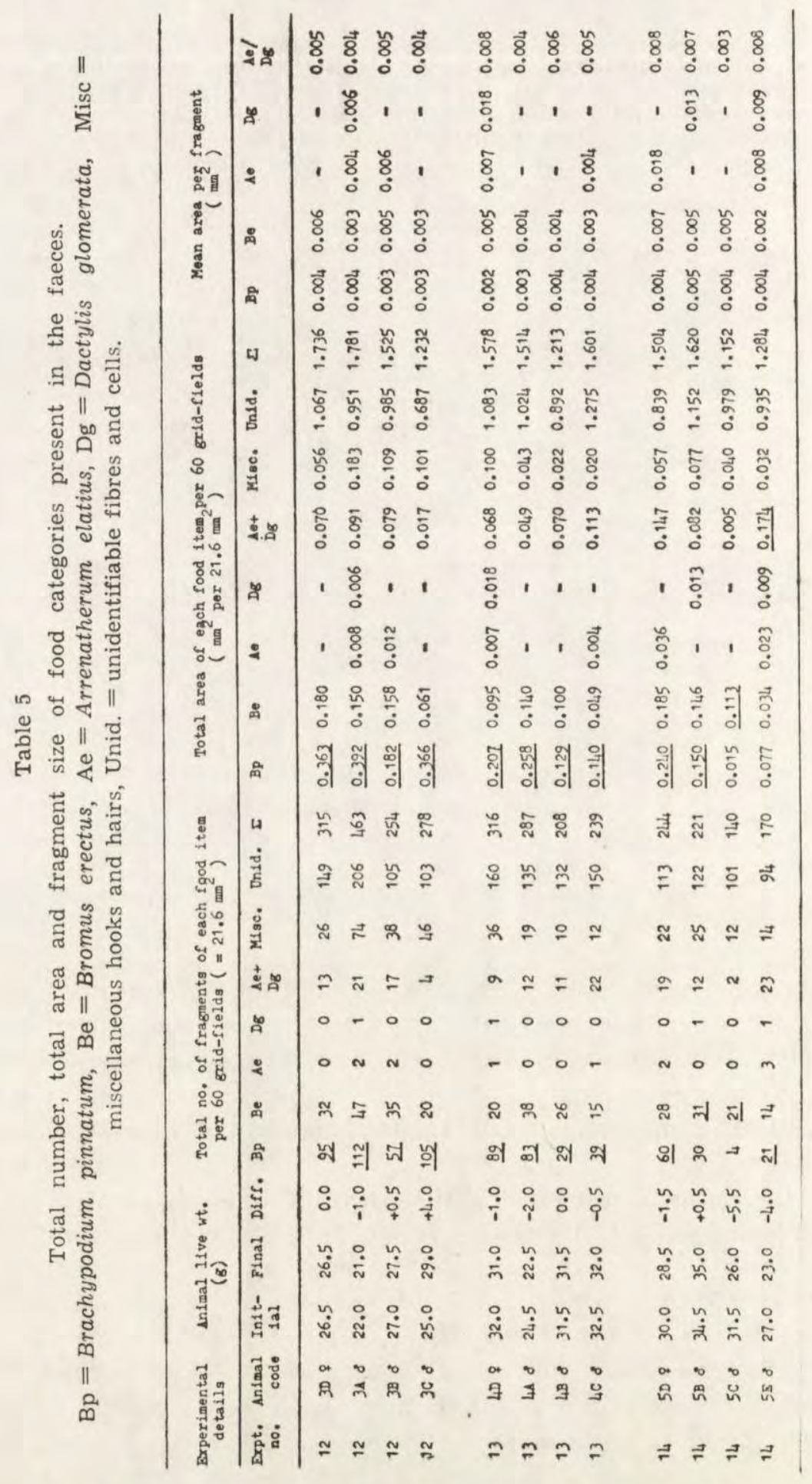




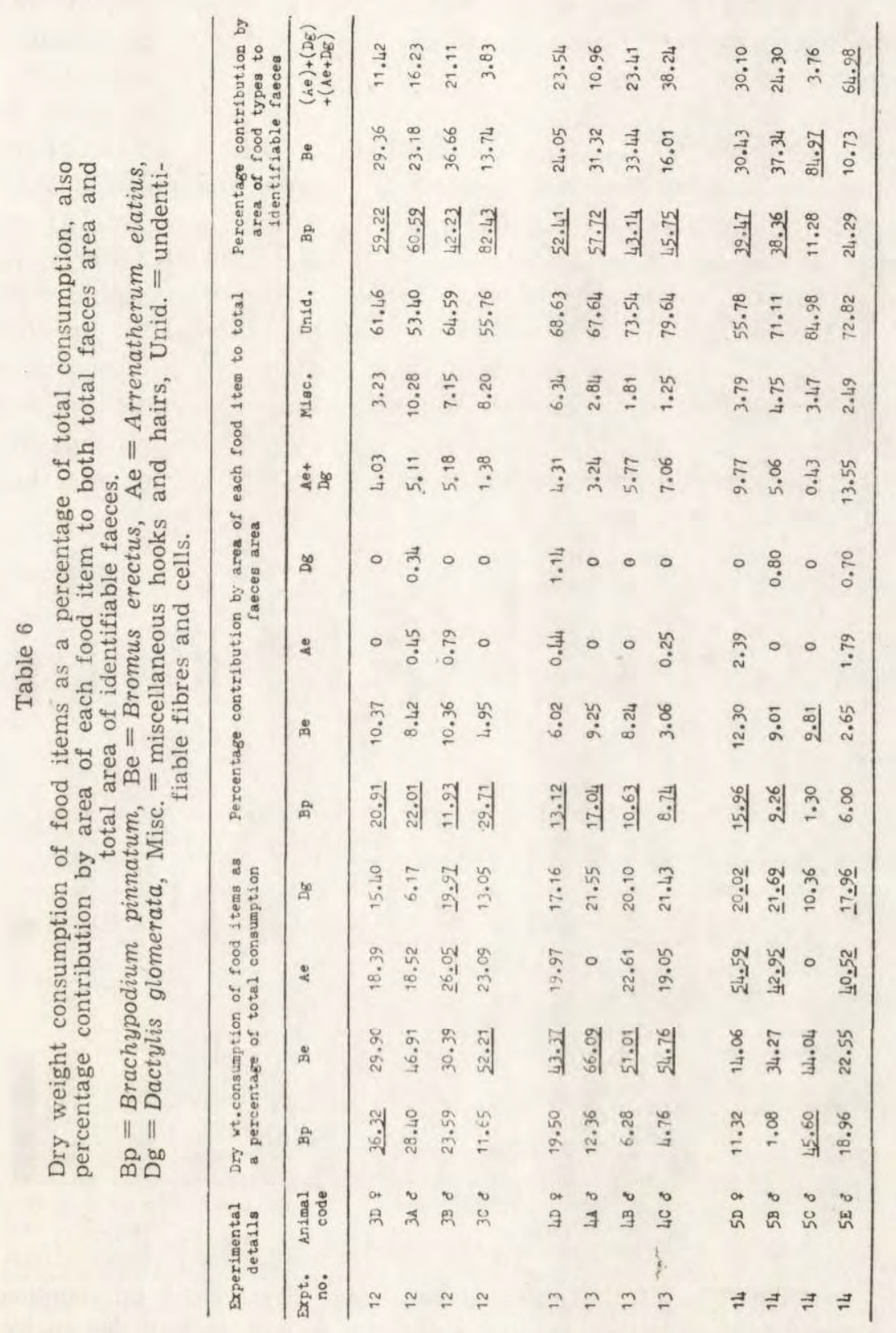


observed food preference and that inferred from faecal analysis. The dry weight consumption of each food item by each of the experimental animals was expressed as a percentage of each individual's total consumption; similarly, the area of each food category observed in each individual's faecal preparations was expressed as a percentage of the total fragment area measured. The results are shown in Table 6 where it can be seen that between 60 and 88 per cent of the faecal materials could not be assigned to a specific food type, the mean being 74 per cent. It follows that determination of "diet composition" was, of necessity, based on an average of one-quarter of the total faecal material sampled. Because of the varying proportions of specifically identifiable food items, and to facilitate comparison between food and faecal composition, the areas of each specific faecal food item were expressed as a percentage of the total area of identifiable items. Figure 3 compares percentage consumption with percentage identifiable faeces composition. In 11 out of 12 cases B. pinnatum was clearly over represented by the faecal

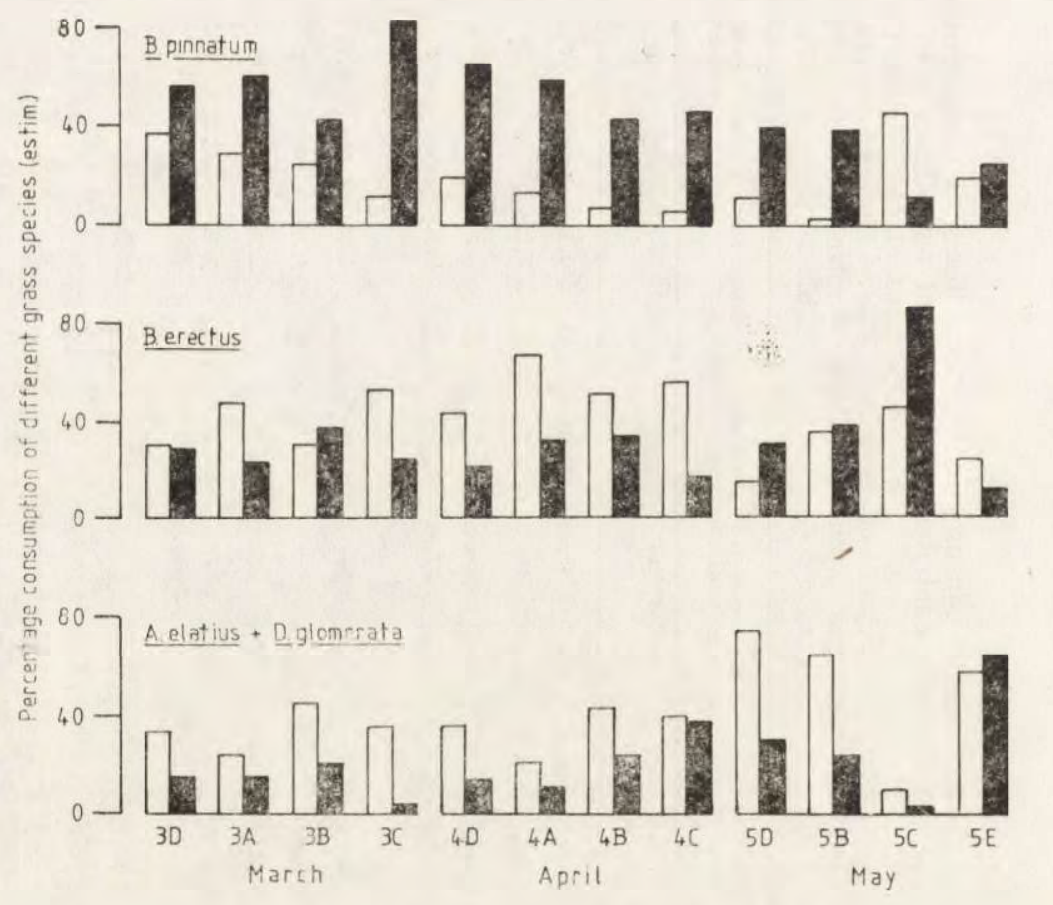

Fig. 3. Comparison of the observed percentage dry weight consumption of the different food grasses (open columns) and the percentage contribution by area of the different grasses to the identifiable portion of the faeces produced from this consumption (closed columns). The code numbers refer to individual voles, details of which are given in Table 5. 


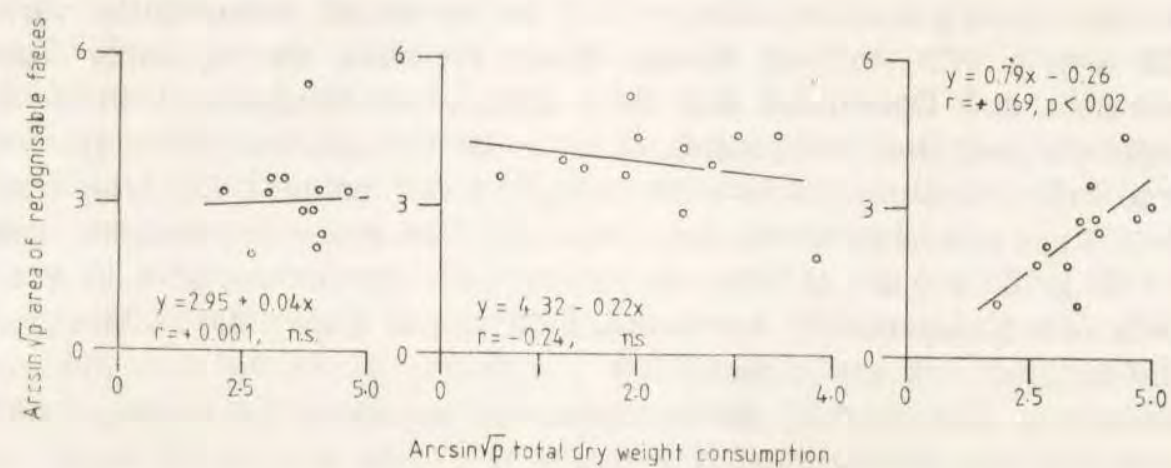

Fig. 4. Arcsin square root transformations of the percentage contribution by specifically identified food items to the total area of recognisable food items in the faeces regressed against the arcsin square root transformations of the observed dry weight percentage contribution of the different food items to total consumption.

analysis technique; $B$. erectus was under represented in 7 out of 8 March -April samples, and over represented in 3 of the 4 May ones; A. elatius and $D$. glomerata combined were under represented in 11 out of 12 cases. Despite the varying consumption to faeces ratio for each food type over time (see Fig. 3) it was considered worthwhile to explore the possibility of establishing an overall correction factor for each food type. Using arcsine square root transformations the area of a particular food item expressed as a percentage of the total area of recognisable fragments, was regressed against the dry weight of the same food item expressed as a percentage of total dry weight consumption (Fig. 4). No significant relationships could be established in the cases of $B$. pinnatum and $B$. erectus, although that for $A$. elatius/D. glomerata proved significant at the $2 \%$ level.

\section{DISCUSSION}

It is not surprising that most feeding studies on Microtus agrestis have shown grasses to be the primary food source (Summerhayes, 1941; Godfrey, 1953; Chitty, Pimentel \& Krebs, 1968; Hansson, 1970 \& 1971; Evans, 1973; Ferns, 1976) for it occurs most commonly among tall grasses, along field hedgerows, and in young tree plantations where the grass is lush. An exception to this general rule was provided by Myllymäki (1959), who found in southern Finland that $M$. agrestis preferred herbs to the available grasses and sedges.

In this one-year laboratory study, total grass intake by adult animals 
averaged $21.35 \mathrm{~g}$ fresh wt. indiv. ${ }^{-1} \mathrm{~d}^{-1}$. Fresh weight consumption varied with season (the highest values being recorded during early June, November and December) but these differences disappeared when dry weight consumption was considered. It is not thought that the voles were specifically choosing foods with a high water content for free water was always available in the water bottles. The mean dry weight intake of $6.29 \mathrm{~g}_{\text {indiv }}^{-1} \mathrm{~d}^{-1}$ is fully consistent with the values of $6.30 \mathrm{~g}$ and $7.10 \mathrm{~g}$ found respectively by Hansson (1971) and Ferns (1976). Moreover, allowing for a mean digestibility coefficient of $52.8^{0} \%$ and applying Hansson \& Grodzinski's (1970) regression equation for average daily metabolic rate (Rodent $A D M R=19.94 W^{-0.50}$ ) to a vole of mean live weight $28.67 \mathrm{~g}$, it can be shown that the daily grass consumption should be ca. $6.07 \mathrm{~g}$ dry wt. at $20^{\circ} \mathrm{C}$. It can be concluded that the present findings for dry weight consumption by $M$. agrestis are not untypical.

All four grass species used in this study are described by Duffey, Morris, Sheail, Ward, Wells \& Wells (1974) as being coarse and characteristic of the retrogression of Festuca spp. sward following cessation of grazing. They are probably not an ideal food source for $M$. agrestis; indeed, in laboratory experiments Richards (1981) showed that, of the fifteen grasses occurring on Rough Common, Festuca rubra L. was much preferred over the four species dealt with here (see also Ferns, 1976). Even so, this species, along with Agropyron repens L., Deschampsia caespitosa L., Helicotrichon pratense L., Holcus lanatus L. and Poa angustifolia L. only occurred sporadically in small patches over the research area. The remaining five species, Agrostis stolonifera L., Agrostis tenuis Sibth., Briza media L., Festuca ovina L. and Trisetum flavescens L. were all rare (Gibson, 1976). It is highly improbable that the more palatable of these species could have collectively supported the known maximum field vole population of $100-120 \mathrm{ha}^{-1}$ (Richards, 1981). It was considered justifiable therefore to assume that $M$. agrestis in the field relied upon the four most common grasses of Rough Common as their major source of nourishment, which accounts for their use in the laboratory trials of food preference.

Of particular interest in the results from this study was the order of preference exhibited for the four food grasses on offer. Only in June, July 1979 and March, April 1980 were clear preferences demonstrated, B. erectus being the preferred food in March, April 1980 and late June 1979, B. pinnatum in early June 1979 , and A. elatius and D. glomerata in July 1979. Because the different food items preffered in the laboratory had equal availability it must be inferred that the various foods changed in quality over time. The nature of these changes is, as yet, unknown but there is an apparent correlation between the food preferences shown 
by $M$. agrestis and the phenology of the different grass species. According to Duffy et al. (1974) new leaf growth in B. erectus occurs from late-March to May inclusive, April to May is the period of rapid growth for $B$. pinnatum, while $A$. elatius and $D$. glomerata reach their maximum growth rate during May to July. Clearly, the implication is that given the opportunity $M$. agrestis will select new, succulent growth in preference to older, tougher, and perhaps distasteful grasses. The absence of a demonstrable food choice in Autumn and Winter no doubt reflects the fact that the months March to July encompass the major growth periods for the grasses under consideration. Outside this period the quality differences between the grasses were presumably insufficient to exert a significant pressure on $M$. agrestis food selection.

Given that at certain times of the year at least, $M$. agrestis does exhibit a choice between different food items, there remains the question as to whether any method, other than direct observation, will provide reliable information about a) actual food consumption and b) food preference. Digestibility coefficients through time offer one possibility for quantitative determination of food consumption; always, of course, providing that they and faecal output can be determined accurately. A useful check on results so obtained can be carried out by using the known digestibility coefficient in conjunction with the ADMR regression equation of Hansson \& Grodziński (1970) - see early part of discussion. A major problem associated with this approach lies in the variable nature of digestibility coefficients with both food type and time. In this study the coefficients varied between $33.6 \%$ and $67.8 \%$, giving a mean value of $52.8 \%$; these figures are in accord with the mean dry matter digestibility of $50 \%$ reported by Hansson (1971) and a range of $33.1 \%$ to $56.8 \%$. In both studies higher values were noted in Spring as opposed to Winter. Clearly, a rough approximation of food consumption can be obtained by employing a digestibility coefficient of $50 \%$ and applying it to know faecal production; more desirable is the use of a realistic seasonal coefficient in conjuncton with both faecal production and the $A D M R$ linear regression. Given agreement between the results of the two calculations one can be reasonably confident of having estimated consumption with a fair degree of accuracy.

More instransigent is the identification of a suitable indirect method for determining food preference in the field. Hansson (1970) recommended the use of stomach contents since the least amount of digestion occurs there, Ferns (1976) quite rightly pointed out that such material reflects only the composition of the most recent meal. With an adult full stomach fresh weight of 1.0 to $1.5 \mathrm{~g}$ (Hansson, 1971) it is clear that an intake of $21.35 \mathrm{~g}$ fresh wt of food indiv ${ }^{-1} \mathrm{dy}^{-1}$ requires that the stomach be 
emptied and refilled between 14 and 21 times per day. Unless many individuals are killed to provide an adequate sample on each sampling occasion it is obvious that inferences about food preference based on stomach content analyses must be treated with caution.

Both Hansson $(1970,1971)$ and Ferns (1976) expressed doubts about the validity of faecal analysis for the assessment of food preferences in the field, the main objection raised was the differential digestibility of different food items. Until the present work no one, to our knowledge, had subjected this proposition to experimental testing by comparing directly the composition of food intake with that of faecal output. Our own studies show that faecal analysis, whether by percentage occurrence, fragment number or fragment area, does not reflect food preference.

Aproximately $25 \%$ of the faecal material was specifically identifiable and analysis of this proportion indicated that $B$. pinnatum was the most frequently preferred food. This finding is in marked contrast to the known consumption, in that $B$. pinnatum was generally the least preferred of all the four experimental foods. Attempts to correct this, and similar anomalies were only partially successful. For each food type we separately regressed $\sin ^{-1} \sqrt{P}$ of faecal proportion against $\sin ^{-1} \sqrt{P}$ of intake proportion. In the case of the "tougher" grass species (B. erectus and $B$. pinnatum) the slopes of the regression lines did not differ significantly from zero, both species were clearly over represented in the faeces when their contribution to total intake was low and under represented when it was high. Such findings accord well with the proposition that $B$. erectus and $B$. pinnatum are only consumed in large quantities when they are "succulent" i.e. during March, April and early June. It was presumably because of this phenomenon that Chitty et al. (1968) found, from experiments conducted during February and March, that $B$. pinnatum was eaten extensively by $M$. agrestis in field enclosures. In fact, their results indicate that approximately $60 \mathrm{~g}$ fresh wt of "greenstuff" was destroyed by one adult every day; with a likely consumption of ca. $20 \mathrm{~g}$ fresh wt $\mathrm{dy}^{-1}$ it would appear that field voles destroy three times as much grass as they consume. The arcsine square root regression for the combined "softer" grasses (A. elatius and D. glomerata) proved to be statistically significant $(y=0.79 x-0.26, r=+0.69$, d.f. $=10, p<0.02$ ) and could therefore be used to derive a reasonable estimate of the actual consumption of these species. Although consistently under represented in the faeces the discrepancy between faecal content and food intake is largest when these two species form a high proportion of total consumption, again an indication that the preferred food grasses are the most "succulent" ones available. 
On the current evidence we conclude that without appropriate correction factors, faecal analysis gives rise to misleading inferences about food preferences. Because of the changing "quality" of food with time it is not always possible to establish such correction factors, and hence iaecal analysis is unsuitable for the determination of food preferences in the field. Stomach analyses, in addition to the problems of turnover time and especially where retention time is long and digestion high, must be subject to simlar drawbacks. These conclusions clearly have relevance beyond studies of $M$. agrestis alone, namely in the wider context of food preference studies. It would appear, despite their artificial nature, that well designed "cafeteria" type experiments are the most likely indirect method of providing reliable results on food preference.

Acknowledgements: We are most grateful to Ken Marsland and David Loach for the technical assistance they provided during the course of this work.

\section{REFERENCES}

1. Chitty D., Pimentel D. \& Krebs C. J., 1968: Food supply of over-wintered voles. J. Anim. Ecol., 37: 113-120.

2. Duffey E., Morris M. G., Sheail J., Ward L. K., Wells D. A. \& Wells T. E., 1974: Grassland ecology and wildlife management. Chapman \& Hall: 1-281. London.

3. Evans D. M., 1983: Seasonal variations in the body composition and nutrition of the vole Microtus agrestis. J. Anim. Ecol., 42: 1-18.

4. Ferns P. N., 1976: Diet of a Microtus agrestis population in south west Britain. Oikos, 27: 506-511.

5. Gibson C. W. D., 1976: The importance of foodplants for the distribution and abundance of some Stenodemini (Heteroptera: Miridae) of limestone grassland. Oecologia (Berl.), 25: 55-76.

6. Gibson C. W. D., 1976a: The biology of Heteroptera associated with Tor grass: Brachypodium pinnatum L. D. Phil, thesis, Oxford University.

7. Godfrey G. K., 1953: The food of Microtus agrestis hirtus (Bellamy, 1839) in Wytham, Berkshire. Säugetierk. Mitt., 1: 148-151.

8. Hansson L., 1970: Methods of morphological diet micro-analysis in rodents. Oikos, 21: 255-266.

9. Hansson L., 1971: Habitat, food and population dynamics of the field vole Microtus agrestis (L.) in south Sweden. Viltrevy, 8: 267-378.

10. Hannson L. \& Grodziński W., 1970: Bioenergetic parameters of the field vole, Microtus agrestis L. Oikos, 21: 76-82.

11. Metcalfe C. R., 1960: Anatomy of the monocotyledons. I. Graminae, Clarendon Press, Oxford.

12. Myllymäki A., 1959: Bedeutung und Ursachen der Mäusefrasschaden in Finnland. Valt. Maatalouskoetoiminnan Julk., 178: 75-100.

13. Petrusewicz K. \& Macfadyen A., 1970: Producivity of Terrestrial Animals: Principles and Methods. IBP Handbook, 13: xii+1-190. Blackwell Sci. Publ., Oxford. 
14. Richards C. J. G., 1981: Aspects of the population and feeding ecology of Microtus agrestis (L.), the field vole. D. Phil. thesis, Oxford University.

15. Summerhayes V. S., 1941: The effect of voles (Microtus agrestis) on vegetation. J. Ecol., 29: 14-48.

Accepted, May 24, 1983

\author{
J. PHILLIPSON, M. SARRAZIN-COMANS i C. STOMATOPOULOS
}

\title{
KONSUMPCJA POKARMU U MICROTUS AGRESTIS I ZASTOSOWANIE ANALIZY KAEU DO OKRESLENIA PREFERENCJI POKARMOWEJ
}

\section{Streszczenie}

Autorzy postawili sobie za cel sprawdzenie dwóch hipotez: (1) czy konsumpcja ró́żnych pokarmów zjadanych przez $M$. agrestis jest proporcjonalna do dostępności tych pokarmów, oraz (2) czy skład diety określony na podstawie analizy kału odbija preferencję zjadanego pokarmu.

Badania prowadzono w laboratorium na doroslych osobnikach $M$. agrestis. Norniki te zjadały średnio $21.4 \mathrm{~g}$ świeżej trawy (=6.3 $\mathrm{g}$ suchej masy) na dobę. Srednia roczna strawność wynosiła u nich $52.8 \%$ (Tabela 1 ). Zwierzętom podawano do jedzenia, jesienią i zimą, 4 pospolite gatunki traw $w$ takiej proporcji w jakiej występowały w warunkach naturalnych (Ryc. 1,2). Wiosną i latem preferowały one bardziej soczyste gatunki. W ciągu roku współczynnik strawności wahał się od 33.6 do $67.8 \%$, a najwyższe wartości osiągal również na wiosnę i w lecie.

Po przeprowadzeniu wielu różnorodnych obliczeń statystycznych (Tabela 2, 3; Ryc. 3,4 ) oraz porównań z wynikami uzyskanymi przez innych badaczy odnośnie analiz pokarmu, przemian energetycznych itp. (Tabela 5,6 ) autorzy konkludują, że analiza kału, bez użycia odpowiedniej poprawki daje wyniki błędne jeżeli chodzi o preferencję pokarmową. Wiąże się to głównie $\mathrm{z}$ niedoszacowaniem lub przeszacowaniem niektórych komponentów diety. Ustalenie tej poprawki, w oparciu o stosowane metody i rozumowanie, jest niemożliwe ze względu na ogromną zmienność „jakości" pokarmu. Zatem analiza kału nie nadaje się do oznaczania wybiórczości pokarmowej $M$. agrestis w terenie. 


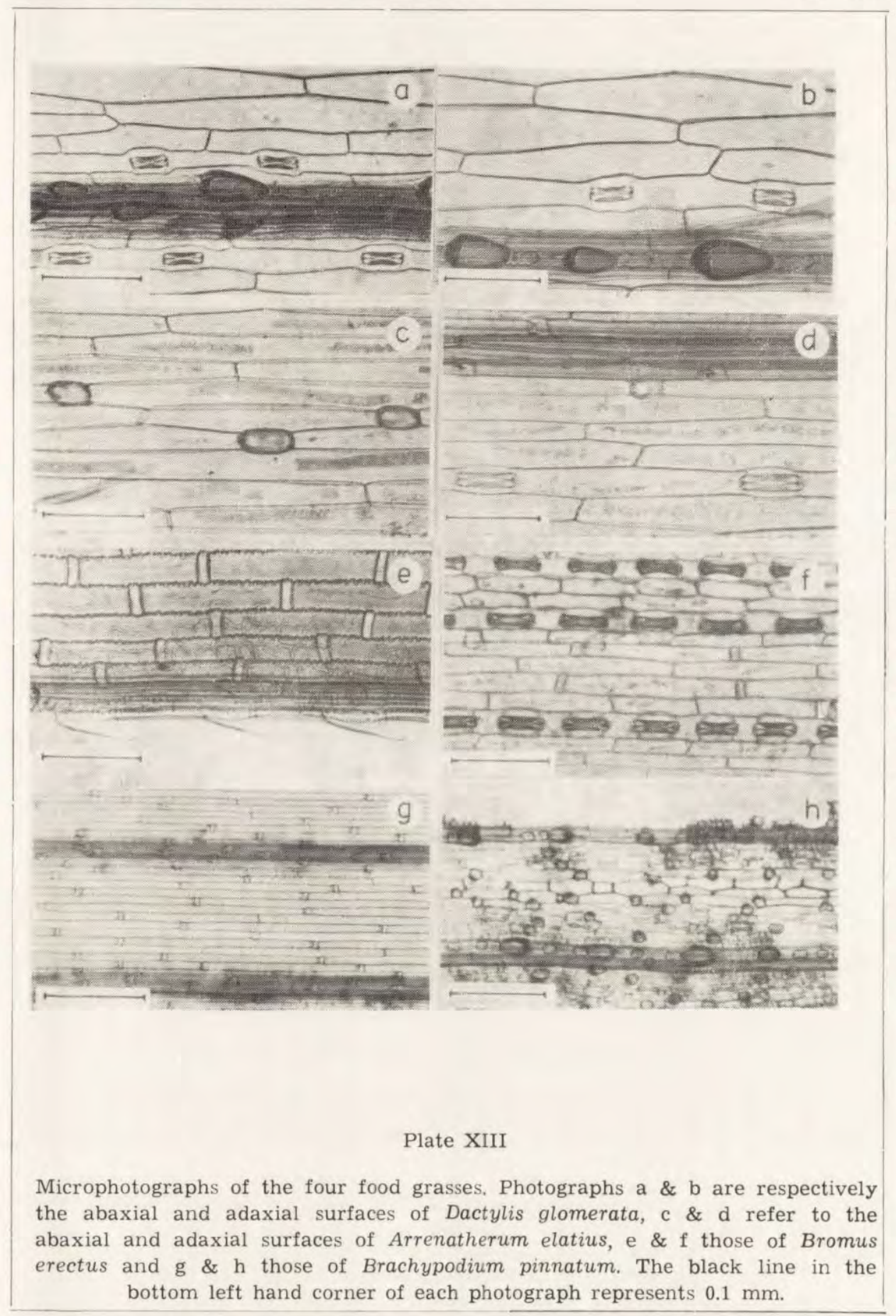

J. Phillipson et al.

auctores phot. 